\title{
Amazon Sailfin Catfish Pterygoplichthys pardalis (Loricariidae) in Bangladesh: A Critical Review of Its Invasive Threat to Native and Endemic Aquatic Species
}

\author{
Mohammad Y. Hossain ${ }^{1}$, Robert L. Vadas Jr. ${ }^{2}$, Ramon Ruiz-Carus ${ }^{3, *,+}$ and Shams M. Galib ${ }^{1,4}$ \\ 1 Department of Fisheries, Faculty of Agriculture, University of Rajshahi, Rajshahi 6205, Bangladesh; \\ yeamin.fish@ru.ac.bd (M.Y.H); shams.m.galib@durham.ac.uk (S.M.G.) \\ 2 Washington Department of Fish and Wildlife, Habitat Program, 600 Capitol Way North, \\ Olympia, WA 98501-1091, USA; Robert.Vadas@dfw.wa.gov \\ 3 FWC, Florida Fish \& Wildlife Research Institute, 100 Eighth Avenue S.E., St. Petersburg, FL 33701-5020, USA. \\ 4 Department of Biosciences, University of Durham, South Road, Durham DH1 3LE, UK \\ * Correspondence: ramrc@tampabay.rr.com \\ + Retired.
}

Received: 29 December 2017; Accepted: 20 February 2018; Published: 22 February 2018

\begin{abstract}
The Amazon sailfin catfish Pterygoplichthys pardalis is native to the Amazon River basin. It has since expanded its range to North America, the Caribbean, and more recently to South Asia, as with some of its congeners. Our paper reviews recent data from Bangladesh, clarifies taxonomic identification, and examines the potential effects of P. pardalis and congeneric species on local aquatic ecosystems and elsewhere in South Asia. Range expansions there probably reflect aquarium releases and escapes from aquaculture farms, as exacerbated by dispersal due to storm flooding and in impacted waters like irrigation canals. Given their potential ecosystem-level effects, we also review potential control mechanisms and human use for these invasive loricariids.
\end{abstract}

Keywords: Hypostominae; suckermouth armored catfishes; sailfin catfishes; ecosystem threats; Brahmaputra River drainage; Bangladesh

\section{Introduction}

Suckermouth armored catfishes (Loricariidae) are in the largest family of the order Siluriformes, with about 80 genera and over 700 species that naturally occur in South and Central American waters [1]. The members of the genus Pterygoplichthys (Siluriformes: Loricariidae), including synonym genus Liposarcus, typically have nine or more dorsal-fin rays and are commonly known as sailfin catfishes [1-4]. Four Pterygoplichthys species, Pterygoplichthys pardalis (Castelnau, 1855), Pterygoplichthys multiradiatus (Hancock, 1828), Pterygoplichthys disjunctious (Weber, 1991), and Pterygoplichthys anisitsi (Eigenmann \& Kennedy, 1903), are phylogenetically close and have very similar external morphology and biology [2,5-7]. Sailfin catfishes have been traditionally consumed and marketed in their native Amazon and Orinoco drainages. However, most importantly, the algivorous habits of sailfin catfishes caused a high demand for them in the ornamental aquarium fish trade, which stimulated cultivation of these fishes beyond their natural ranges $[4,8,9]$.

Bangladesh has a tropical-monsoonal climate, with seasonally varying precipitation and a mild winter from December to February [10]. Bangladesh has $\approx 266$ fish species in freshwater ecosystems, including species introduced for aquaculture for human consumption and biocontrol of malaria [11]. Although aquaculture is done in closed-pond systems, fishes have escaped to rivers and floodplains throughout the country during monsoon and flooding events [12]. Consequently, at least 24 exotic food 
fish species and $\approx 25$ exotic ornamental fish species are established in Bangladeshi freshwaters [11-16]. The effects of these introduced fishes on local ecosystems have not been properly assessed, and a lack of information precludes their management.

Our study reviews recent data of Pterygoplichthys spp. in Bangladesh [16], clarifies taxonomic identification, and examines the potential effects of $P$. pardalis and congeneric species on local aquatic ecosystems and those elsewhere in South Asia. To assess the invasive threat, we examine the trophic, habitat, and reproductive ecology of sailfin catfishes. Notably, globally oriented, exotic fish treatises reported loricariids under Hypostomus spp. because their systematics was still unknown $[17,18]$, whereas that of Fuller et al. [4] focused on North America.

\section{Recent Data and Update on Bangladesh}

Eighteen suckermouth armored catfishes were captured from five localities in the Ganges-Brahmaputra River drainage of Bangladesh during 2007-2012 (Table 1). Subsequent captures of these fishes have been informally reported and not substantiated with voucher specimens. In addition, numerous reports of Hypostomus plecostomus (Linnaeus, 1758) in 2004-2013 were most likely taxonomic misidentifications of Pterygoplichthys spp. (e.g., [11,13-15]).

We identified all suckermouth armored catfishes caught here as Amazon sailfin catfish, P. pardalis (Castelnau, 1855), with the first documented occurrence in this country being in 2007 (Table 1; Figure 1). The timing for the first capture is similar to that found in India for this species and other congeneric catfishes, including P. pardalis and P. disjunctious during 2007-2008 in the eastern Calcutta Wetlands, India (a Ramsar Site) and P. anisitsi during 2008-2009 in the River Ganga at Patna, Bihar State, India [19].

The Bangladeshi specimens for all years except 2009 measured 334-394 mm in standard length (mean \pm standard deviation $(\mathrm{SD})=355 \pm 120 \mathrm{~mm}$ ). Their total weights were $588-612 \mathrm{~g}$ (mean $\pm \mathrm{SD}=600 \pm 12 \mathrm{~g}$ ). All were undoubtedly adults, as $P$. pardalis become sexually mature at $\approx 250 \mathrm{~mm}$ standard length (SL) [20-23] with minimal sexual dimorphism, albeit adult females are generally more robust and abundant than adult males during the spawning season $[8,24,25]$. As our specimens were mostly under $400 \mathrm{~mm}$ in total length, they were apparently in prime reproductive condition as adults [22]. These specimens were noticeably smaller than the maximum size seen for other Pterygoplichthys spp. in Florida (USA) and other invaded areas [26,27].

We did not find any nest (spawning) burrows in Bangladesh, but the six P. pardalis specimens from 2009 were juveniles, being 78-112 $\mathrm{mm}$ in SL (mean $92 \mathrm{~mm}$ ) and 7.9-24.5 g in total weight. This suggests some reproductive success for this species in Bangladesh. Additionally, their occurrence in five different localities of the Ganges-Brahmaputra River drainage (north- and southwestern floodplains) (Figure 2) suggests possible dispersal. Further efforts to establish the spawning success of $P$. pardalis in this river drainage will require strategic sampling based on the genus's unique ecology. First, loricariids appear to favor mainstem and sometimes brackish habitats for juvenile/adult rearing, whereas tributaries likely are nursery (larval) refuges, given their favorable biophysical conditions [8,20,24-28]. Hence, upstream sampling is likely to reveal younger life stages of P. pardalis. Second, the spawning period is usually long, with a summer peak in P. multiradiatus: March to September (and occasionally through February) in Taiwan [24], April or May to September in the USA [29,30], and throughout the year in Hawaii, USA [31]. Likewise, P. disjunctious spawns during spring to fall (especially June-July) in Florida, USA [25-27], and P. pardalis is known to burrow (spawn) during March in Mexico [20]. These results suggest that water temperature, rather than day length, controls the spawning periodicity of sailfin catfishes, so sampling during proper thermal conditions may better reveal the males' nest burrows in tributaries. Pterygoplichthys species show unique reproductive habits in (a) building spawning burrows along shorelines near steep, non-rocky banks found at river bends; and (b) providing male-parental care in Asia [24,31,32] and elsewhere [20,30,33,34], which makes them harder to eradicate $[8,25,26]$. Although loricariids are normally aggressive and territorial [9], they can become locally abundant where invasive (see below) and may school when at higher densities [8]. Higher non-winter flows may benefit $P$. disjunctivus recruitment by inundating soft-bank spawning habitats [25] and enhancing 
nursery habitats, but extreme seasonal-flow fluctuations likely limit algal food supplies and the fish's reproductive success [27]. Hence, spring-fed streams like Florida's St. Johns River may provide good invasion habitats, despite being below their thermal optimum [24,26]. Cold-hypoxic conditions, however, may prevent reproductive success, for example, Florida's springs [26].

The most plausible cause for the presence of P. pardalis in Bangladesh is similar to other Eurasian countries with Pterygoplichthys species: aquarium releases and escapes from aquaculture farms [9,19,24,32,35-40]. In Bangladesh, several cyprinid (minnow) species are often cultured together with sailfin catfishes [16], and there are several large cities along the Ganges-Brahmaputra-Padma-Meghna River basin that provide ample opportunities for aquarium trade that could further disperse sailfin catfishes. Probably, P. pardalis reached Bangladesh and India similarly as Vietnam [36], via importation with other exotic species from Singapore, peninsular Malaysia, or Taiwan during the 1980s and through subsequent accidental or intentional release(s). Aquarium releases and escapes from aquaculture farms, notably from the ornamental fish industry, have also brought Pterygoplichthys species to establish reproducing populations in southern North America, Puerto Rico, and Hawaii, USA [4,8,9,25,27,34,41-43], with dispersal being facilitated by hurricanes, lesser storms, and anglers [26]. Subterranean passage is also possible for sailfin catfishes in Florida, given its karst (limestone-cave) geology [26].

Table 1. Summary of Amazon sailfin catfish (Pterygoplichthys pardalis: Siluriformes: Loricariidae) specimens caught in the Ganges-Brahmaputra River drainage of Bangladesh (see Figure 2). The first three sets of fish (A, B, C) were caught in the northwest (Rajshahi and Rangpur Divisions) along the Jamuna (Brahmaputra) River, with morphometric/meristics data provided by Hossain et al. [16]. The last two sets of fish (D, E) were caught along the Ganges River. Deposition of voucher specimens is provided.

\begin{tabular}{ccccccc}
\hline Date & Division & Fishery & Gear & Habitat & Number & Preservation \\
\hline 16 Jun 2007 & Rajshahi $^{\text {A }}$ & Commercial & Lift-net & Irrigation canal & 3 & Yes \\
28 Jun 2007 & Rajshahi $^{\text {B }}$ & Commercial & Lift-net & Irrigation canal & 2 & Yes \\
3 Jul 2007 & Rangpur $^{\text {C }}$ & Commercial & Lift-net & Irrigation canal & 5 & No \\
22 Sep 2009 & Rajshahi $^{\text {D }}$ & Private & Cast net & Urban fish pond & 6 & Yes \\
1 Apr 2012 & Khulna $^{\text {E }}$ & Private & Cast net & Rural fish pond & 2 & No \\
\hline
\end{tabular}

(A) Caught near the railways at Kahalu Upazila, Bogra District. Preserved and retained at the Zoology Laboratory of Kahalu Degree College in Bogra. (B) Caught in a wetland at Gabtali Upazila, Bogra District. Preserved and retained at the Shukhanpukur Saiyad Ahmed College in Bogra. (C) Caught from an irrigation canal in Gaibandha District, Rangpur Division (northwestern Bangladesh). (D) Caught at Paschim Vatapara, Nimpara, Charghat Upazila, Rajshahi District (northwestern Bangladesh). One specimen preserved and retained at the Department of Fisheries, University of Rajshahi. (E) Caught by a farmer in Agmondia village near a branch of the Ganges River; Kaliganj Upazila, Jhenaidah District, Khulna Division (southwestern Bangladesh). Taxonomic identification was based on the criteria of Weber [2,5], Ruiz-Carus and Grier [33], and Armbruster and Page [44]. The discarded fish $(C, E)$ were identified from voucher photographs. After identification, six voucher specimens were fixed and preserved in $10 \%$ aqueous formalin and retained for future reference. 

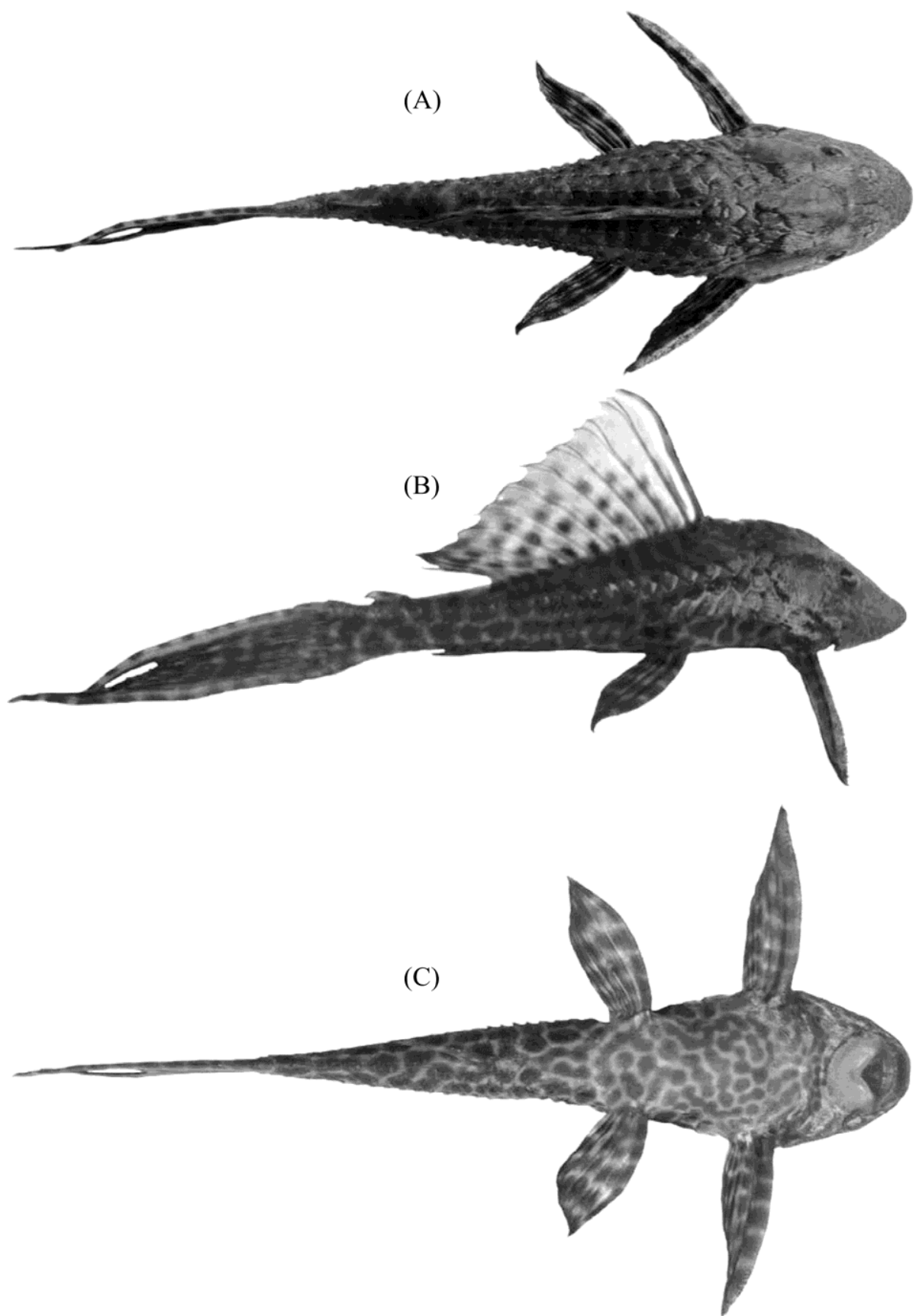

Figure 1. Photographs of a juvenile (164 mm total length) Pterygoplichthys pardalis (Castelnau, 1855) captured from location D (see Figure 2). (A) Dorsal view: pigmentation of the head has a geometric pattern. (B) Lateral view: skin pigmentation pattern consists of dark spots on light background; dark spots are slightly coalescent on the sides of the head. (C) Ventral view: dark spots are mostly coalescent on the lower venter. 


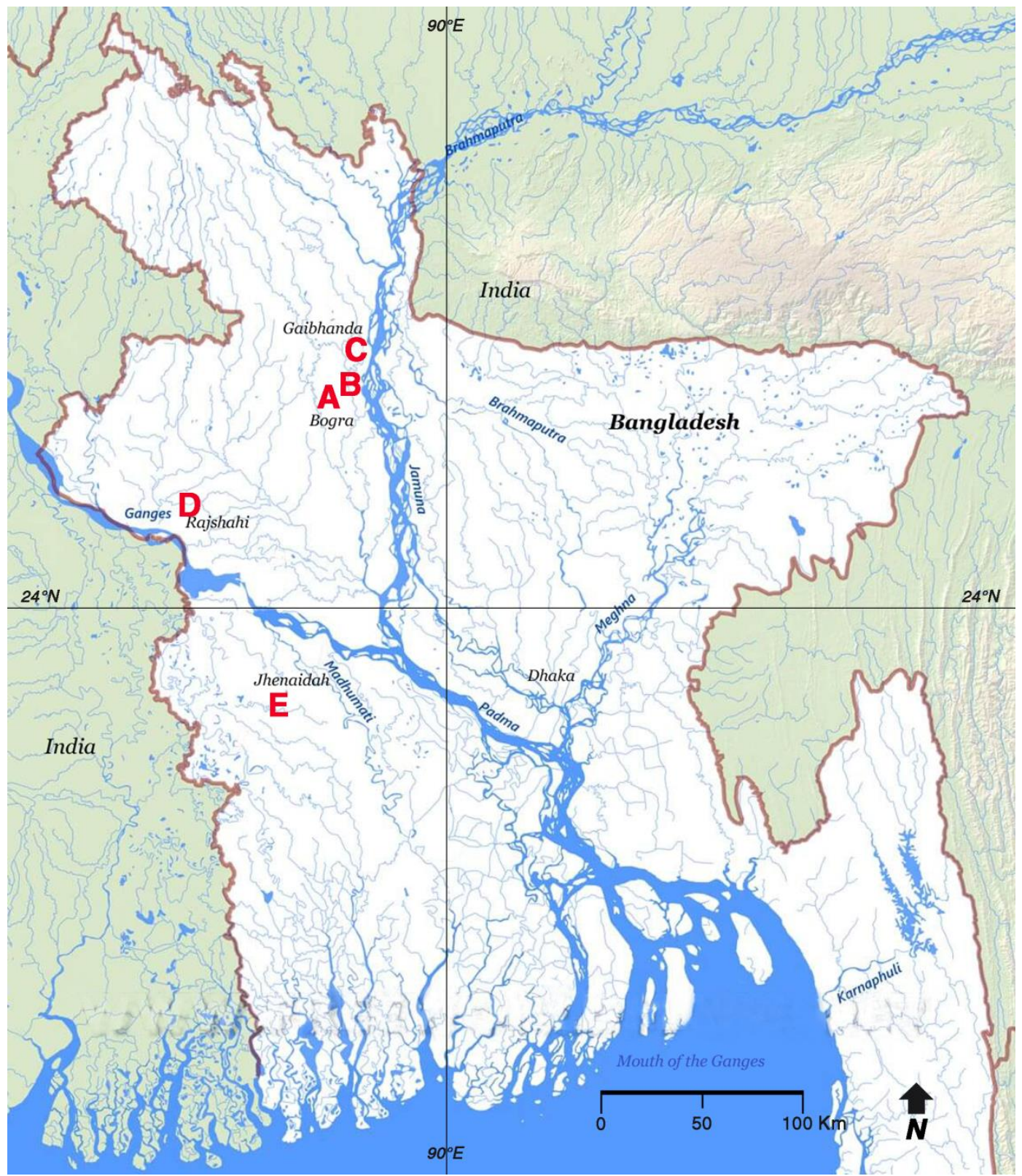

Figure 2. Localities of Bangladesh where Pterygoplichthys pardalis (Castelnau, 1855) was captured on the north- and southwest floodplains of the Ganges-Brahmaputra River drainage: (A) Kahalu Upazila $\left(24^{\circ} 49^{\prime} 53^{\prime \prime} \mathrm{N}-89^{\circ} 15^{\prime} 47^{\prime \prime} \mathrm{E}\right)$, and (B) Gabtali Upazila (245' $\left.53^{\prime \prime} \mathrm{N}-89^{\circ} 30^{\prime} 24^{\prime \prime} \mathrm{E}\right)$,

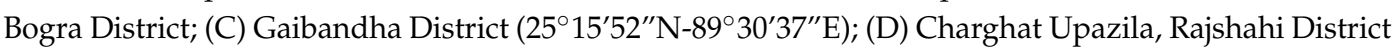

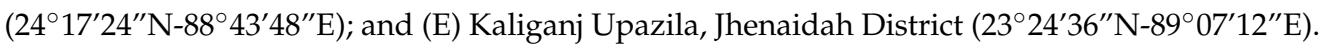

\section{Remarks on Pterygoplichthys pardalis Identification}

P. pardalis, P. multiradiatus, P. disjunctivus, and P. anisitsi lack an elevated supraoccipital process, their posterior supraoccipital process is enclosed by three scutes, and they have two scutes between their temporal and second predorsal scutes $[2,5,33,44]$. P. pardalis and P. multiradiatus both have ventral pigmentation patterns of uncoalesced, dark spots on a light background, whereas $P$. disjunctivus shows a vermiculate (worm-like) pattern and P. anisitsi has light spots on a dark background $[2,5,33,44]$. P. pardalis differs from P. multiradiatus in having a geometric pigmentation pattern on top of the head, unlike the latter species' irregularly distributed, dark spots, but the two species can hybridize with other Pterygoplichthys spp. in North America [20,21,26,27] and Asia [19,35]. Moreover, Weber [2] reported 
that $P$. pardalis has spots of variable size that coalesce on the lower venter, but form vermiculations on the side of the head (Figure 1). Hence, the earlier identification of P. multiradiatus in Bangladesh [16] is herein revised to P. pardalis, as has also occurred in Florida [26]. The related exotic loricariid reported from Bangladesh as H. plecostomus [11,13-15], is actually a Pterygoplichthys sp. based on our review of the data. Indeed, these two genera are closely related and often confused with each other. Their major difference is in their dorsal fin, for which Hypostomus spp. have seven soft rays, whereas Pterygoplichthys spp. have a longer fin with nine or more soft rays.

\section{Invasive Biology and Potential Ecosystem Effects}

Pterygoplichthys species are considered a severe ecologic and freshwater-fisheries threat in Eurasia $[9,16,24,32,35,36,38,39]$ and North America $[8,34,41]$ for various reasons that should apply to aquatic ecosystems in Bangladesh.

Pterygoplichthys species $[9,32,38,40,45]$ and confamilials in America $[28,34,46-51]$ are considered demersal herbivores (with subterminal mouths) of value for algal control in aquaria $[4,8,16,19,23,35,36,39,52]$, and their release or escape into the wild should be discouraged. Indeed, the expanding ranges of loricariids, particularly sailfin catfishes, into North America (since 1957 in Florida, but particularly during the 1990s) $[27,53,54]$ are threatening the smaller-bodied, native minnows and other non-game fishes of peninsular Florida, Texas, other southern states (USA), Puerto Rico, and Mexico $[4,8,9,34,43,46]$.

P. multiradiatus shows rapid growth, high fecundity, and female-biased sex ratios [24] that usually cause explosive population growth upon introduction $[4,8,16,34]$. We should expect similar population dynamics in Bangladesh for P. pardalis and the iteroparous P. disjunctivus [25,27], the former having become the dominant fish species in the Langat River of peninsular Malaysia [22]. Such fast growth has often led to maturation at smaller body sizes [25], and the release of armored catfishes into the wild when they outgrow aquaria $[8,9]$. The longevity of $P$. disjunctivus may not be much beyond five years in Florida [27].

The r-selected ("weedy") population dynamics (sensu [55,56]) of Pterygoplichthys and other loricariids is advantageous in temperate zones [18] but has negative effects on native fish and wildlife. Sailfin catfishes usually cause: (a) water-pollution, sanitary, and greenhouse-gas problems (via their feces and decomposition after fish kills); (b) pathogen spread to native fishes like minnows; and (c) harassment of threatened Florida manatee (Trichechus manatus latirostris) $[8,20,21,26,53,54]$ that (like human disturbances) elevates manatee overwintering-activity levels in warm-inshore waters [9,54]. Such temporary attachments allow skin-grazing for algae and other epibionts, and perhaps thermoregulation on the warm bodies of manatees [8,20,21,26,54]. On the Malaysian Peninsula, P. pardalis showed similar growth and body condition during the wet and dry seasons of 2003-2004 in the river Langat, which never dropped below $1 \mathrm{~m}$ in depth [22]. Negative allometric growth is typical for this species and P. multiradiatus in Eurasia, as they become relatively thinner with age [22,24].

Pterygoplichthys spp. have several anti-predatory adaptations [4]. Their external bony plates and deep bodies may protect them from native predators even in mainstem habitats $[24,40,41]$, so their abundance is not easily controlled where they invade rivers $[8,26]$. They are also known to regenerate appendages like pectoral fins [19], and despite these sedentary fishes' vulnerability to piscivorous birds, defensive erection of their dorsal and pectoral spines pose a mortal (asphyxiation) danger to such predators $[8,34,57]$. Younger loricariids, however, are more vulnerable to predation because of their thinner armor and smaller body sizes [27]. Moreover, avian, piscine, reptilian, and mammalian predators have sometimes learned how to eat sailfin catfishes in Florida, given the latter's vulnerable ventral side [21]. So diurnal cover-seeking and night-feeding activities by Pterygoplichthys juveniles likely reflects vulnerability to such predators during daylight hours in clearwater streams $[23,26,27,35]$. Pterygoplichthys spp. have interfered with Filipino, Mexican, and Floridian fisheries by impacting native fin- and shellfishes; damaging, soiling, and crowding fishing/aquaculture gear and injuring desired fishes and anglers with their spines and overpopulation; thus, raising boat-fuel costs and 
eliminating fishing jobs $[8,9,20,32,36,41]$. Fortunately, such bycatch interference can be reduced by curtailing nocturnal-netting activities $[8,26]$, whereas bait-fishing is ineffective for catching these catfishes [52].

The generalized-ecological habits of sailfin catfishes worsen their predation and habitat/food competition impacts on invaded, aquatic ecosystems. Large populations can significantly impact native herbivorous and more-carnivorous fishes, given alteration and reduction of aquatic-insect and other arthropod foods by direct (invertivory) and/or indirect (algivory) means that effectively shorten food chains in Asia $[9,16,24,38,40]$ and North America [4,8,34]. Indeed, P. multiradiatus and its congenerics show generalized, demersal feeding that contributes to their invasion success $[34,43]$. They ingest algae, detritus, incidental sand, and various benthic invertebrates (including small bivalves) in Asia [16,24] and elsewhere [8,26,58-60], sometimes even feeding on floodplain detritus [34] when traveling on land. They are known to eat artificial fish feed but not native-Asian fishes in aquaria [19], and their identifiable feces are worm-like [8,53]. Because plant foods are clearly dominant over animal prey [8], sailfin catfishes are not true omnivores, but rather incidental feeders of zoobenthos trapped within plant materials. Indeed, the guts of herbivorous loricariids contain microbes and fungi that degrade cellulose [60]. The demersal feeding of sailfin catfishes may possibly further reduce native-fish abundances (e.g., minnows) by incidentally ingesting their eggs $[8,24,33,34]$. Such feeding by bed-plowing can also uproot native aquatic macrophytes [52,61], thus (a) reducing native-plant abundances in beds of submersed-aquatic vegetation that native-phytophylic fishes depend on; and (b) creating turbidity and cutting plant mats that could change sunlight exposure [34,62]. Because cyprinids are often the dominant fish family in South Asian wetlands [63], sailfin catfishes are threats to aquatic food webs there [8], particularly in estuarine waters where their detritivorous diets are less unique [20]. Their trophic habits are also well-suited for impacted waters, where plant foods and/or other exotic fishes predominate [8]. However, in freshwater habitats, their relatively unique feeding niches could potentially allow increases in total-fish biomass, despite biodiversity losses, as is common for other exotic-freshwater fishes [64]. Sailfin catfishes are also known to use bedrock and cover/crevice structures (of boulder and woody nature) as rearing (resting/foraging) habitats $[21,26,27]$.

Sailfin catfishes are hardy macrohabitat generalists that escape harsh (dry/cold) weather in their shoreline-rearing burrows (given ample coelomic-fat storage) or on land (including short-distance dispersals) for up to $30 \mathrm{~h}$ (given air-breathing). They inhabit shoreline and shallower waters of soft or rocky beds in slower-moving streams (e.g., canals), and they generally inhabit clear but polluted (eutrophic/hypoxic) lentic and thermally heated waters (e.g., sewage outfalls) in Eurasia [9,19,24,32,35-37,39,40], the southern USA [21,25-28,34,53,57,65], and Ibero-America $[8,18,41,66,67]$. However, older (juvenile/adult) $P$. pardalis and other sailfin catfishes have recently occupied shallower, brackish waters of southern Florida and southeastern Mexico after storm flooding, though they apparently do not spawn there [20]. For these warmer regions, such rearing fishes prefer freshwater to mesohaline salinities $(\leq 8-13 \mathrm{ppt})$ based on field studies and experiments, which suggests greater feeding and invasion opportunities than previously seen there and elsewhere $[4,20]$. Israeli $P$. pardalis and $P$. disjunctivus inhabit shallow-brackish waters with salinities near 2 vs. $0.5 \mathrm{ppt}$, respectively [35]. General water-quality preferences for loricariids (but with wider abiotic ranges) include toxic/hypoxic conditions (dissolved oxygen down to $3 \mathrm{ppt})$, warmer temperatures $\left(21-29^{\circ} \mathrm{C}\right)$, neutral $\mathrm{pH}(7 \pm 1)$, and relatively low water hardness $(4-20 \mathrm{mg} / \mathrm{L})[4,8,20,26,39]$.

Moreover, the burrowing and tunneling activities of spawning (adult male) and rearing (refuging) Pterygoplichthys species can undermine canal banks and lake shorelines $[20,36,68]$. This can cause siltand erosion-control problems in reservoirs and streams of Florida $[23,26,27,30]$ and Hawaii $[4,31,42]$ that impact benthic spawning and rearing fishes $[8,9,24,34,35]$ and injure hikers [51]. Such impacts are exacerbated by deep (steep-sided and non-vegetated) shorelines in reservoirs, which facilitate 
shoreline erosion by both sailfin catfishes and Florida's alligators [8,30]. It is unknown whether sailfin catfishes reduce nuisance algae in the field to provide some ecosystem benefit [26].

\section{Control, Eradication, and Human Uses.}

Although local eradication of sailfin catfishes can be expensive [51] and is ineffective if these exotic fishes have had time to expand their ranges [26], several alternatives exist to remove them from natural and artificial waters [8,69].

First, encourage anglers to preferentially catch adult and egg masses during the spawning season (a) by hand or (b) with attractants and traps, gig spears, or various netting gears $[8,19,20,24-26,32,35,43,52]$. Such work, which should include boating, snorkeling, and/or SCUBA diving in deeper waters, is best done when the catfishes surface for air or congregate in spring-fed habitats during cold snaps or at night [21,26]. Although loricariids' flesh and eggs may be tasty [34], they are underutilized [69] and the flesh's high ash and heavy-metal contents limit its use as fertilizer and human food (except as a condiment in Mexico) [8,64]. Nevertheless, sailfin catfishes could provide fish meal and perhaps cattle feed, crab bait, and surimi (Japanese food), given their high protein and fatty-acid content [8]. Other potential uses for loricariids include handcrafting of the dried skin $[64,65]$, and making of soap, biofuel, collagen products, and digestive enzymes [8].

Second, because armored catfishes and other exotic-tropical fishes are often first found in irrigation canals ('ditches'), wetlands like rice paddies, and artificial ponds, and typically overwinter (with reduced feeding) in thermally heated waters $[4,8,18,25,46,53,70-72]$ where pathogens can spread [39], such habitats should be isolated [9] to prevent fish/disease invasions into other freshwater habitats of Bangladesh and elsewhere by rainstorms, etc. Indeed, ditches, ponds, and streams lacking riparian vegetation often show extensive heating and evaporation [73-77] that may promote warm-adapted, desiccation-resistant exotics like sailfin catfishes, particularly in the face of climate change.

Third, winter freezing — though rarely observed in northern Bangladesh—often reduces loricariids in southern-temperate climates $[8,26]$. Because low water levels can exacerbate freezing effects, periodic winter drawdowns of artificial ditches and lentic habitats can help reduce exotic, asexually reproducing plants [78,79] and armored catfishes to the depth of drawdown. Indeed, P. disjunctivus may benefit from stable-level, invaded habitats of North America, in contrast to its native, seasonally flashy habitats in South American rivers [27].

Fourth, besides net-blocking during spawning migrations [26], control mechanisms like fish barriers may not stop these adaptable, rheophilic fishes, which can withstand velocities above $1 \mathrm{~m} / \mathrm{s}$ given their attachable mouths [23]. Likewise, pesticide control and bank armoring to reduce loricariid burrowing $[8,34]$ would likely impact aquatic ecosystems unfavorably.

Fifth, the most effective way-from a large-scale perspective-to prevent further spread of P. pardalis in Bangladeshi waters is through general public-awareness campaigns against indiscriminate release of young and adult sailfin catfishes into local waters [24].

\section{Conclusions}

The presence of P. pardalis in Bangladesh needs consideration in future aquatic management and conservation plans. Hence, long-term surveys are needed to assess the current distribution and to predict the ecologic effects of this wide-ranging, invasive species on the already-threatened fish assemblages of northwestern Bangladesh [80]. Better knowledge of catfish-invasion dynamics can be gained through risk assessments and ecologically predictive and socioeconomic modeling $[8,68,81,82]$. We concur with Asian colleagues $[9,10]$ that subtropical and tropical countries, such as Bangladesh, should develop national protocols and guidelines for invasive species through legislative control and quarantining of the pet trade. Management plans for the protection and rational use of biodiversity should also discourage funding and support for activities that introduce or spread 
invasive species. These plans should also promote broad-scale cooperation and international exchange of regional information.

Acknowledgments: We thank the following colleagues: Carl J. Ferraris, Jr. (National Museum of Natural History, Washington, DC, USA), Jonathan W. Armbruster (Auburn University, Alabama, USA), Larry M. Page and Robert H. Robins (Florida Museum of Natural History, Gainesville, FL, USA), Tyson R. Roberts (Mahidol University, Thailand), Armando T. Wakida-Kusunoki (Centro Regional de Investigación Pesquera, Yukalpeten, Yucatan, Mexico), Llyn C. French (FWC-Fish \& Wildlife Research Institute, St. Petersburg, Florida, USA), and Washington State librarians Sharon Brewer and Ruth Keller. Hal A. Beecher (Washington Department of Fish \& Wildlife, Olympia, WA, USA; retired) critically reviewed the manuscript. The Kahalu Degree College (Bogra, Bangladesh) provided laboratory facilities for the senior author. We acknowledge the constructive comments of two anonymous referees.

Conflicts of Interest: The authors declare no conflict of interest. The hosting institutions had no role in the collection, design, analysis, or interpretation of data; in the writing of the manuscript, and in the decision to publish it.

\section{References}

1. Nelson, J.S. Fishes of the World, 4th ed.; John Wiley \& Sons: Hoboken, NJ, USA, 2006.

2. Weber, C. Révision du genre Pterygoplichthys sensu latu (Pisces, Siluriformes, Loricariidae). Rev. Fr. Aquariol. 1992, 19, 1-36.

3. Ferraris, C.J. Checklist of catfishes, recent and fossil (Osteichthyes: Siluriformes), and catalogue of Siluriform primary types. Zootaxa 2007, 1418, 1-300. [CrossRef]

4. Fuller, P.L.; Nico, L.G.; Williams, J.D. Nonindigenous fishes introduced into inland waters of the United States. Am. Fish. Soc. Spec. Pub. 1999, 27, 1-622.

5. Weber, C. Nouveaux taxa dans Pterygoplichthys sensu lato (Pisces, Siluriformes, Loricariidae). Rev. Suisse Zool. 1991, 98, 637-643.

6. Montoya-Burgos, J.I.; Weber, C.; Le Bail, P. Phylogenetic relationships within Hypostomus (Siluriformes: Loricariidae) and related genera based on mitochondrial D-loop. Rev. Suisse Zool. 2002, 109, 369-382. [CrossRef]

7. Armbruster, J.W. Phylogenetic relationships of the suckermouth armoured catfishes (Loricariidae) with emphasis on the Hypostominae and the Ancistrinae. Zool. J. Linn. Soc. 2004, 141, 1-80. [CrossRef]

8. CEC (Commission for Environmental Cooperation). Trinational Risk Assessment Guidelines for Aquatic Alien Invasive Species: Test Cases for the Snakeheads (Channidae) and Armored Catfishes (Loricariidae) in North American Inland Waters; CEC Publications: Montreal, Canada, 2009.

9. Krishnakumar, K.; Raghaban, R.; Prasad, G.; Bijukumar, A.; Sekharan, M.; Pereira, B.; Ali, A. When pets become pests-Exotic aquarium fishes and biological invasions in Kerala, India. Curr. Sci. India 2009, 97, $474-476$.

10. Islam, Md M; Ruhul Amin, A.S.D.; Parker, S.K. Bangladesh. Pallewatta, N., Reaser, J.K., Gutierrez, A.T., Eds.; In Invasive Alien Species in South-Southeast Asia: National Reports \& Directory of Resources; Global Invasive Species Programme: Cape Town, South Africa, 2003; pp. 7-20.

11. Rahman, A.K.A. Freshwater Fishes of Bangladesh, 2nd ed.; Zoological Society of Bangladesh: Dhaka, Bangladesh, 2005.

12. Biswas, B.C.; Panigrahi, A.K. Diversity of exotic fishes and their ecological importance in southwestern part of Bangladesh. Int. J. Innov. Res. Sci. Tech. 2014, 1, 129-131.

13. Mohsin, A.B.M.; Galib, S.M. Handbook on Exotic Ornamental Fishes of Bangladesh; Bangladesh Fisheries Information: Rajshahi, Bangladesh, 2013.

14. Galib, S.M. Exotic Fishes of Bangladesh: Suckermouth Catfish, Hypostomus Plecostomus (Linnaeus, 1958). Available online: http://en.bdfish.org/2011/05/exotic-fishes-of-bangladesh-suckermouth-catfishhypostomus-plecostomus-linnaeus-1758 (accessed on 20 December 2017).

15. Galib, S.M.; Mohsin, A.B.M. Exotic ornamental fishes of Bangladesh. Bangladesh J. Prog. Sci. Tech. 2010, 8, 255-258.

16. Hossain, M.Y.; Rahman, M.M.; Ahmed, Z.F.; Ohtomi, J.; Islam, A.B.M.S. First record of the South American sailfin catfish Pterygoplichthys multiradiatus in Bangladesh. J. Appl. Ichthyol. 2008, 24, 718-720.

17. Welcomme, R.L. Register of international transfers of inland fish species. FAO Fish. Tech. Pap. 1981, 213, $1-120$.

18. Welcomme, R.L. International introductions of inland aquatic species. FAO Fish. Tech. Pap. 1988, 294, 1-318. 
19. Sinha, R.K.; Sinha, R.K.; Sarkar, U.K.; Lakra, W.S. First record of the southern sailfin catfish, Pterygoplichthys anisitsi Eigenmann \& Kennedy, 1903 (Teleostei: Loricariidae), in India. J. Appl. Ichthyol. 2010, 26, 606-608.

20. Capps, K.A.; Nico, L.G.; Mendoza-Carranza, M.; Arevalo-Frias, W.; Ropicki, A.J.; Hellpern, S.A.; Rodiles-Hernandez, R. Salinity tolerance of non-native suckermouth armoured catfish (Loricariidae: Pterygoplichthys) in south-eastern Mexico: Implications for invasion and dispersal. Aquat. Conserv. 2011, 21, 528-540. [CrossRef]

21. Nico, L.G. Nocturnal and diurnal activity of armored suckermouth catfish (Loricariidae: Pterygoplichthys) associated with wintering Florida manatees (Trichechus manatus latirostris). Neotrop. Ichthyol. 2010, 6, 893-898. [CrossRef]

22. Samat, A.; Shukor, M.N.; Mazlan, A.G.; Arshad, A.; Fatimah, M.Y. Length-weight relationship and condition factor of Pterygoplichthys pardalis (Pisces: Loricariidae) in Malaysia Peninsula. Res. J. Fish. Hydrobiol. 2008, 3, $48-53$.

23. Nico, L.G.; Jelks, H.L.; Tuten, T. Non-native suckermouth armored catfishes in Florida: description of nest burrows and burrow colonies with assessment of shoreline conditions. ANSRP Bulletin 2009, 9, 1-30.

24. Liang, S.H.; Wu, H.P.; Shieh, B.S. Size structure, reproductive phenology, and sex ratio of an exotic armored catfish (Liposarcus multiradiatus) in the Kaoping River of southern Taiwan. Zool. Stud. 2005, 44, 252-259.

25. Gibbs, M.A.; Shields, J.H.; Lock, D.W.; Talmadge, K.M.; Farrell, T.M. Reproduction in an invasive exotic catfish Pterygoplichthys disjunctivus in Volusia Blue Spring, Florida, USA. J. Fish Biol. 2008, 73, 1562-1572. [CrossRef]

26. Nico, L.G.; Butt, P.L.; Johnston, G.R.; Jelks, H.L.; Kail, M.; Walsh, S.J. Discovery of South American suckermouth armored catfishes (Loricariidae, Pterygoplichthys spp.) in the Santa Fe River drainage, Suwannee River basin, USA. BioInvasions Rec. 2012, 1, 179-200. [CrossRef]

27. Gibbs, M.A.; Kurth, B.N.; Bridges, C.D. Age and growth of the loricariid catfish Pterygoplichthys disjunctivus in Volusia Blue Spring, Florida. Aquat. Invasions 2013, 8, 207-218. [CrossRef]

28. Power, M.E. Habitat quality and the distribution of algae-grazing catfish in a Panamanian stream. J. Anim. Ecol. 1984, 53, 353-374. [CrossRef]

29. Gestring, K.B.; Shafland, P.L.; Stanford, M.S. Status of the exotic Orinoco sailfin catfish (Pterygoplichthys multiradiatus) in Florida. Fla. Sci. 2010, 73, 122-137.

30. Gestring, K. Shoreline Erosion Assessment of Loricariid Catfishes in Florida; Non-Native Fish Laboratory Report; Florida Fish \& Wildlife Conservation Commission: Boca Raton, FL, USA, 2004.

31. Yamamoto, M.N.; Tagawa, A.W. Hawaii's Native and Exotic Freshwater Animals; Mutual Publishing: Honolulu, HI, USA, 2000.

32. Chavez, J.M.; de la Paz, R.M.; Manohar, S.K.; Pagulayan, R.C.; Vi, J.R.C. New Philippine record of South American sailfin catfishes (Pisces: Loricariidae). Zootaxa 2006, 1109, 57-68.

33. Ruiz-Carus, R.; Grier, H.J. The exotic armored catfishes (Loricariidae) and Hoplosternum littorale (Callichthyidae) in Florida, particularly in the Hillsborough River. In Proceedings of the 4th Tampa Bay Area Scientific Information Symposium (BASIS 4), Treat, S.E., Ed.;. St. Petersburg, FL, USA, 27-30 October 2003.

34. Hoover, J.J.; Killgore, K.J.; Cofrancesco, A.F. Suckermouth catfishes: threats to aquatic ecosystems of the United States? ANSRP Bulletin 2004, 4, 1-9.

35. Golani, D.; Snovsky, G. Occurrence of suckermouth armored catfish (Siluriformes, Loricariidae, Pterygoplichthys) in inland waters of Israel. BioInvasions Rec. 2013, 2, 253-256. [CrossRef]

36. Levin, B.A.; Phuong, P.H.; Pavlov, D.S. Discovery of the Amazon sailfin catfish Pterygoplichthys pardalis (Castelnau, 1855) (Teleostei: Loricariidae) in Vietnam. J. Appl. Ichthyol. 2008, 24, 715-717. [CrossRef]

37. Piazzini, S.; Lori, E.; Favilli, L.; Cianfanelli, S.; Vanni, S.; Manganelli, G. A tropical fish community in thermal waters of southern Tuscany. Biol. Invasions 2010, 12, 2959-2965. [CrossRef]

38. Page, L.M.; Robins, R.H. Identification of sailfin catfishes (Teleostei: Loricariidae) in southeastern Asia. Raffles B. Zool. 2006, 54, 455-457.

39. Keszka, S.; Panicz, R.; Tański, A. First record of the leopard pleco, Pterygoplichthys gibbiceps (Actinopterygii, Loricariidae) in the Brda River in the centre of Bydgoszcz (northern Poland). Acta Ichthyol. Piscat. 2008, 38, 135-138. [CrossRef]

40. Özdilek, Ş.Y. Possible threat for Middle East inland water: An exotic and invasive species, Pterygoplichthys disjunctivus (Weber, 1991) in Asi River, Turkey (Pisces: Loricariidae). E.Ü. Su Ürünleri Dergisi 2007, 24, 303-306. 
41. Wakida-Kusunoki, A.T.; Ruiz-Carus, R.; Amador-del-Angel, E. Amazon sailfin catfish, Pterygoplichthys pardalis (Castelnau, 1855) (Loricariidae), another exotic species established in southeastern Mexico. Southwest. Nat. 2007, 52, 141-144. [CrossRef]

42. Devick, W.S. Patterns of introductions of aquatic organisms to Hawaiian freshwater habitats. In New Directions in Research, Management and Conservation of Hawaiian Freshwater Stream Ecosystems; Devick, W.S., Ed.; Proceedings of the 1990 Symposium of Freshwater Stream Biology and Fisheries Management; Hawaii Department of Land and Natural Resources, Division of Aquatic Resources: Honolulu, HI, USA, 1991; pp. 189-213.

43. Nico, L.G.; Martin, R.T. The South American suckermouth armored catfish, Pterygoplichthys anisitsi (Pisces: Loricariidae), in Texas, with comments on foreign fish introductions in the American Southwest. Southwest. Nat. 2001, 46, 98-104. [CrossRef]

44. Armbruster, J.W.; Page, L.M. Redescription of Pterygoplichthys punctatus and description of a new species of Pterygoplichthys (Siluriformes: Loricariidae). Neotrop. Ichthyol. 2006, 4, 401-409. [CrossRef]

45. Hubbs, C.; Lucier, T.; Garrett, G.P.; Edwards, R.J.; Dean, S.M.; Marsh, E. Survival and abundance of introduced fishes near San Antonio, Texas. Tex. J. Sci. 1978, 30, 369-376.

46. Power, M.E. Grazing responses of tropical freshwater fishes to different scales of variation in their food. Environ. Biol. Fish. 1983, 9, 103-115. [CrossRef]

47. Power, M.E. The importance of sediment in the grazing ecology and size class interactions of an armored catfish, Ancistrus spinosus. Environ. Biol. Fish. 1984, 10, 173-181. [CrossRef]

48. Power, M.E. Predator avoidance by grazing fishes in temperate and tropical streams: Importance of stream depth and prey size. In Predation: Direct and Indirect Impacts in Aquatic Communities; Kerfoot, W.C., Sih, A., Eds.; University Press of New England: Dartmouth, NH, USA, 1987; pp. 333-351.

49. Power, M.E.; Dudley, T.L.; Cooper, S.D. Grazing catfish, fishing birds, and attached algae in a Panamanian stream. Environ. Biol. Fish. 1989, 26, 285-294. [CrossRef]

50. Power, M.E. Resource enhancement by indirect effects of grazers: Armored catfish, algae, and sediment. Ecology 1990, 71, 897-904. [CrossRef]

51. Pfeiffer, E. Armored Catfish Wreaking Havoc in South Florida Lakes. Yahoo News. Available online: https:/ / www.yahoo.com/news/blogs/sideshow/armored-catfish-wreaking-havoc-south-florida-lakes182812663.html (accessed on 20 December 2017).

52. Ludlow, M.E.; Walsh, S.J. Occurrence of a South American armored catfish in the Hillsborough River, Florida. Fla. Sci. 2014, 54, 48-50.

53. Gibbs, M.; Futral, T.; Mallinger, M.; Martin, D.; Ross, M. Disturbance of the Florida manatee by an invasive catfish. Southeast. Nat. 2010, 9, 635-648. [CrossRef]

54. Nico, L.G.; Loftus, W.F.; Reid, J.P. Interactions between non-native armored suckermouth catfish (Loricariidae: Pterygoplichthys) and native Florida manatee (Trichechus manatus latirostris) in artesian springs. Aquat. Invasions 2009, 4, 511-519. [CrossRef]

55. Krebs, C.J. Ecology: The Experimental Analysis of Distribution and Abundance, 5th ed.; Harper \& Row: New York, NY, USA, 2010.

56. Glick, P.; Stein, B.A.; Edelson, N.A. (Eds.) Scanning the Conservation Horizon: A Guide to Climate Change Vulnerability Assessment; National Wildlife Federation: Washington, DC, USA, 2011.

57. Bunkley-Williams, L.; Williams, E.H., Jr.; Lilystrom, C.G.; Corujo-Flores, I.; Zerbi, A.J.; Aliaume, C. The South American sailfin catfish, Liposarcus multiradiatus (Hancock), a new exotic established in Puerto Rican fresh waters. Caribb. J. Sci. 1994, 30, 90-94.

58. Soares, M.G.M.; Almeida, R.G.; Junk, W.J. The trophic status of the fish fauna in Lago Camaleão, a macrophyte dominated floodplain lake in the middle Amazon. Amazoniana 1986, 9, 511-526.

59. Nonogaki, H.; Nelson, J.A.; Patterson, W.P. Dietary histories of herbivorous loricariid catfishes: Evidence from $\delta^{13} \mathrm{C}$ values of otoliths. Environ. Biol. Fish. 2006, 78, 13-21. [CrossRef]

60. Walker, B. The fish with the folded mouth. Aquarium Series II 1968, 1, 36-43.

61. CBIF (Canadian Biodiversity Information Facility). Integrated Taxonomic Information System (ITIS). Available online: http:/ / www.cbif.gc.ca/eng/integrated-taxonomic-information-system-itis/?id=1381347793621 (accessed on 20 December 2017).

62. Patil, S.R.; Patil, S.S.; Sathe, T.V. Preliminary analysis of diversity status with reference to Pisces from major wetlands of Ajara tahsil of Kolhapur district, Maharashtra, India. Biolife 2015, 3, 12-15. 
63. Sagouis, A.; Cucherousset, J.; Villéger, S.; Santoul, F.; Boulêtreau, S. Non-native species modify the isotopic structure of freshwater fish communities across the globe. Ecography 2015, 38, 979-985. [CrossRef]

64. Cagauan, A.G. Exotic aquatic species introduction in the Philippines for aquaculture-A threat to biodiversity or a boom to the economy? J. Environ. Sci. Manage. 2007, 10, 48-62.

65. Page, L.M.; Espinosa-Pérez, H.; Findley, L.T.; Gilbert, C.R.; Lea, R.N.; Mandrak, N.E.; Mayden, R.L.; Nelson, J.S. Common and Scientific Names of Fishes from the United States, Canada, and Mexico, 7th ed.; American Fishes Society: Bethesda, MD, USA, 2013.

66. Val, A.L.; de Almeida-Val, V.M.F. Fishes of the Amazon and their environment: physiological and biochemical aspects. Zoophysiology 1995, 32, 1-245.

67. Burgess, W.E. An Atlas of Freshwater and Marine Catfishes-A Preliminary Survey of the Siluriformes; T.F.H. Publications: Neptune City, NJ, USA, 1989.

68. Sato, M.; Kawaguchi, Y.; Nakajima, J.; Mukai, T.; Shimatani, Y.; Onikura, N. A review of the research on introduced freshwater fishes: new perspectives, the need for research, and management implications. Landsc. Ecol. Eng. 2010, 6, 99-108. [CrossRef]

69. Froese, R.; Pauly, D. (Eds.) FishBase. 2017. Available online: http://www.fishbase.org (accessed on 20 December 2017).

70. USGS (U.S. Geological Survey). Species List of Nonindigenous Fish. Available online: https:// nas.er.usgs. gov/taxgroup / fish/default.aspx (accessed on 20 December 2017).

71. Crossman, E.J. Introduced freshwater fishes: a review of the North American perspective with emphasis on Canada. Can. J. Fish. Aquat. Sci. 1991, 48, 46-57. [CrossRef]

72. Dill, W.A.; Cardone, A.J. History and status of introduced fishes in California, 1871-1996. Fish Bull. Calif. Dep. Fish Game 1997, 178, 1-414.

73. Allan, J.D.; Castillo, M.M. Stream Ecology: Structure and Function of Running Waters, 2nd ed.; Chapman \& Hall: New York, NY, USA, 2007.

74. Reisner, M. Cadillac Desert: The American West and its Disappearing Water; Viking Press: New York, NY, USA, 1986.

75. Vadas, R.L., Jr. The springtime phytoplankton of two calcareous ponds in Ohio. J. Freshwater Ecol. 1992, 7, 407-418. [CrossRef]

76. Vadas, R.L., Jr. Instream-flow needs for anadromous salmonids and lamprey on the Pacific coast, with special reference to the Pacific Southwest. Environ. Monit. Assess. 2000, 64, 331-358. [CrossRef]

77. Nichols, S.A. The use of overwinter drawdown for aquatic vegetation management. Water Res. Bull. 1975, 11, 1137-1148. [CrossRef]

78. Siver, P.A.; Coleman, A.M.; Benson, G.A.; Simpson, J.T. The effects of winter drawdown on macrophytes in Candlewood Lake, Connecticut. Lake Reserv. Manage. 1986, 2, 69-73. [CrossRef]

79. Payne, B.S.; Miller, A.C. Risk assessment, decision analysis, and invasive species. ANSRP Bulletin 2004, 4, $10-13$.

80. IUCN (International Union of Conservation of Nature) Bangladesh. Red List of Bangladesh, vol. 5, Freshwater Fishes; IUCN, Bangladesh Country Office: Dhaka, Bangladesh, 2015.

81. Chang, A.L.; Grossman, J.D.; Spezio, T.S.; Weiskel, H.W.; Blum, J.C.; Burt, J.W.; Muir, A.A.; Piovia-Scott, J.; Veblem, K.E.; Grosholz, E.D. Tackling aquatic invasions: risks and opportunities for the aquarium fish industry. Biol. Invasions 2009, 11, 773-785. [CrossRef]

82. Greenwood, M.F.D. Distribution, spread, and habitat predictability of a small, invasive, piscivorous fish in an important estuarine fish nursery. Fishes 2017, 2, 6. [CrossRef]

(C) 2018 by the authors. Licensee MDPI, Basel, Switzerland. This article is an open access article distributed under the terms and conditions of the Creative Commons Attribution (CC BY) license (http://creativecommons.org/licenses/by/4.0/). 